NBER WORKING PAPER SERIES

\title{
SPECULATIVE TRADING AND STOCK PRICES: EVIDENCE FROM CHINESE A-B SHARE PREMIA
}

\author{
Jianping Mei \\ Jose Scheinkman \\ Wei Xiong \\ Working Paper 11362 \\ http://www.nber.org/papers/w11362
}
NATIONAL BUREAU OF ECONOMIC RESEARCH
1050 Massachusetts Avenue
Cambridge, MA 02138
May 2005

\begin{abstract}
Mei is at New York University, Scheinkman and Xiong are at Princeton University and affiliated with the National Bureau of Economic Research. Scheinkman thanks the National Science Foundation and the Blaise Pascal Research Chair for research support. We thank Yakov Amihud, Cheol Eun, Ed Glaeser, Galina Hale, Lin Peng, Li Wei and participants at several seminars and conferences for valuable comments and suggestions. We are grateful to Chunhui Miao and Aureo de Paula for able research assistance, and to Ming Cai, Kent Hargis, Shenzhen GTA Information Technology Inc. and Boshi Fund Management Company for providing us with the Chinese market data. The views expressed herein are those of the author(s) and do not necessarily reflect the views of the National Bureau of Economic Research.
\end{abstract}

(O2005 by Jianping Mei, Jose Scheinkman, and Wei Xiong. All rights reserved. Short sections of text, not to exceed two paragraphs, may be quoted without explicit permission provided that full credit, including $\odot$ notice, is given to the source. 
Speculative Trading and Stock Prices: Evidence from Chinese A-B Share Premia Jianping Mei, Jose Scheinkman, and Wei Xiong

NBER Working Paper No. 11362

May 2005

JEL No. G0, G1, F3

\begin{abstract}
$\underline{\text { ABSTRACT }}$
The market dynamics of technology stocks in the late nineties has stimulated a growing body of theories that analyze the joint effects of short-sales constraints and heterogeneous beliefs on stock prices and trading volume. This paper examines implications of these theories using a unique data sample from China, a market with stringent short-sales constraints and perfectly segmented dualclass shares. The identical rights of the dual-class shares allow us to control for stock fundamentals. We find that trading caused by investors' speculative motive can help explain a significant fraction of the price difference between the dual-class shares.
\end{abstract}

\author{
Jianping Mei \\ New York University \\ jmei@stern.nyu.edu \\ Jose Scheinkman \\ Department of Economics \\ Princeton University \\ Princeton, NJ 08544-1021 \\ Wei Xiong \\ Princeton University \\ Bendheim Center for Finance \\ 26 Prospect Avenue \\ Princeton, NJ 08450
}




\section{Introduction}

The market dynamics of technology stocks during the late nineties indicates a connection between trading volume and stock price overvaluation. In the case of Palm and $3 \mathrm{Com}$ analyzed by Lamont and Thaler (2003), the market valuation of Palm surpassed its parent company 3Com by over 20 billion dollars in March 2000. At the same time, the available shares of Palm changed hands every week. This pattern was not unique to Palm-3Com, Ofek and Richardson (2003) and Cochrane (2003) document the association between high prices and trading volume in the technology sector.

Although trading volume does not play a role in the classic asset pricing theory, several recent papers have articulated theories that establish a connection between overvaluation and trading volume. Following the basic insights of Miller (1977), Harrison and Kreps (1978) and Chen, Hong and Stein (2002), Scheinkman and Xiong (2003), and Hong, Scheinkman, and Xiong (2004) emphasize the joint effects of short-sales constraints and heterogeneous beliefs on stock prices. When there are limits to the ability of arbitrageurs to short overvalued shares, the marginal buyer of shares tends to be an optimist. This introduces a speculative motive among investors. An asset owner has the option to resell his shares to other more optimistic investors in the future for a profit, and equilibrium prices reflect this option. Typically, as the volatility of the difference in investors' opinions increases, investors trade more often and the value of the resale option also increases. This results in a positive association between trading volume and prices. $^{1}$

It is complicated to directly test overvaluation with data from the Nasdaq stocks because of the difficulty in measuring fundamental values of these stocks. In this paper, we use a unique data set from Chinese stock markets to investigate the joint effects of short-sales constraints and heterogeneous beliefs on trading volume and stock prices. Chinese stock markets are well suited for such an analysis for several reasons. First,

\footnotetext{
${ }^{1}$ Duffie, Garleanu and Pedersen (2002) provide a model that endogenously determines costs of selling short, and links overvaluation to short interest and securities' lending fees.
} 
short-sales of stocks are prohibited by law, and equity derivatives markets were not yet developed during the sample period we use. Second, equity issuance and buy-backs, a common practice that firms use to "arbitrage" the miss-valuation of their own stocks, are severely constrained by the restrictive rules imposed by the government. Third, Chinese stock markets were only re-opened in early 1990s after being closed for nearly half a century. Thus, the stock trading was new to most domestic investors and had created much excitement among them, just like internet stocks were to U.S. investors in the late nineties. More importantly, during the period 1993-2000, several dozen firms offered two classes of shares, class A and class B, with identical rights. Until 2001, domestic investors could only buy A shares while foreign investors could only hold B shares. Despite their identical payoffs and voting rights, class A shares traded on average for $420 \%$ more than the corresponding $\mathrm{B}$ shares. In addition, A shares turned over at a much higher rate $500 \%$ versus $100 \%$ per year for B shares. The high price and heavy share turnover of A shares echo observations on the Nasdaq bubble.

The main hypothesis of our empirical analysis is that the speculative motive of Ashare (domestic) investors generated a speculative component in A-share prices, and this component is positively related to A-share turnover rate. The identical payoff structure of A and B shares allows us to control for stock fundamentals. Thus, we focus on the crosssectional relation between the A-B share premia and the turnover rates. The stringent short-sales constraints avoid potential complications of estimating stocks' short-selling cost. The relatively large panel (75 stocks) also permits us to control for cross-sectional differences in risk and liquidity, as well as the time variation of interest rates and risk premium.

We find that A-share turnover has a significant and positive correlation with the A-B share premia in the period of 1993-2000, and explains, on average, $20 \%$ of the monthly cross sectional variation of this premium.

We also perform several robustness exercises. We control for the effect of liquidity 
using the proportion of no-price-change days in a month for each share. ${ }^{2}$ This does not change much the effect of A-share turnover on the A-B share premia. To determine whether trading in A-share and B-share markets is driven by speculation or liquidity reasons, we examine the cross-sectional correlation between share turnover and asset float (the total market value of publicly available shares) for both A and B shares. Liquidity typically improves as asset float increases. On the other hand, a negative correlation between turnover and float is consistent with implications of speculative trading theories, since when investors are risk averse, it takes a larger dispersion in investors' beliefs for a larger float of shares to change hands. We find a negative and significant association between share turnover and asset float in A-share markets in the period of 1993-2000, suggesting that trading volume of A shares is not mainly a result of liquidity. As further robustness checks, we control for several measures of risk. We find that the strong association between A-share turnover and the A-B premium is still present. We also estimate a panel regression of the A-B share premium on A-share and B-share turnover with time and firm fixed effects. We again find that A-share turnover rate has a positive and highly significant effect on A-B premium. In addition, the variation in the time effect coefficients is well explained $\left(R^{2}=85 \%\right)$ by a linear combination of Chinese and world interest rates and China's political risk premium as measured in the dollar denominated Chinese sovereign bond spread.

Our results corroborate the finding of Cochrane (2003) that there was a positive crosssectional correlation between the market/book ratio of US stocks and their turnover rates during the Nasdaq bubble period of 1996-2000. Our analysis shows that such a relation between stock prices and trading volume is present beyond the specific period of the U.S. markets, and is robust even after controlling for many other factors such as liquidity, discount rate and risk premium.

This paper is also related to the recent literature analyzing the effects of short-sales

\footnotetext{
${ }^{2}$ This variable has been found to be an effective measure of market liquidity in U.S. stock markets and several emerging markets by Lesmond, Ogden, and Trzcinka (1999) and Bekaert, Harvey, and Lundblad (2003).
} 
constraints on stock returns. Jones and Lamont (2002) use U.S. data from the 1920s, when rebate rates, one of the prime shorting costs, were published. They show that stocks with higher shorting costs tend to have lower returns. Chen, Hong, and Stein (2002) use breath of ownership in a firm to proxy for heterogeneous beliefs among investors, while Diether, Malloy, and Scherbina (2002) use the dispersion in analyst forecasts. They all find that stocks associated with higher dispersions of beliefs tend to have lower returns. Our analysis complements these studies by using share turnover, a direct consequence of fluctuations in heterogeneous beliefs, to analyze overvaluation caused by short-sales constraints.

Our analysis also adds to the earlier studies that use the relative pricing between securities with identical or similar fundamentals to analyze the non-fundamental determinants of asset prices. For example, Lee, Shleifer and Thaler (1991) study the discounts of closed-end funds relative to their net asset values, and Froot and Dabora (1999) examine three examples of twin shares, including Royal Dutch and Shell, that are traded in different markets across the world. The relatively simple environment in China's stock markets (strictly enforced restrictions on short-sales, segmentation of A and B shares, and lack of derivatives markets) allows us to identify speculative trading by investors as an important determinant of stock prices.

The rest of the paper is organized as follows. Section 2 describes our empirical hypotheses. In Section 3, we introduce the institutions of the Chinese stock markets. In Section 4, we report our empirical analysis on the A-B share premium. Section 5 further examines the price determinants based on a natural experiment due to the government's policy shift. Section 6 concludes the paper.

\section{Empirical Hypotheses}

Our analysis builds on the growing literature that models the joint effects of heterogeneous beliefs and short-sales constraints for asset prices. In a static setting, a stock's 
price will be upwardly biased when there is a sufficient divergence of opinion because it will only reflect the valuations of the optimists as pessimists simply sit out of the market instead of short-selling (see, e.g., Miller (1977), Chen, Hong and Stein (2002)). In a dynamic setting, these two ingredients also generate a non-fundamental (or speculative) component in asset prices (see, e.g., Harrison and Kreps (1978), Scheinkman and Xiong (2003)). Investors pay prices that exceed their own valuation of future dividends as they anticipate finding a buyer willing to pay even more in the future. The price of an asset exceeds the fundamental value as a result of this resale option.

Investors often differ in their beliefs about stock fundamentals. Overconfidence, a widely observed behavioral bias in psychological studies, provides a convenient way to generate heterogeneous beliefs. ${ }^{3}$ Overconfidence can lead investors to differ in their information processing, i.e., some investors might choose to overweigh a subset of available information in analyzing asset fundamentals, while other investors might overweigh another set, therefore generating heterogeneous beliefs. The difference in investors' beliefs will fluctuate more if investors are more overconfident and differ more in their information processing, or if there is more fundamental uncertainty which leaves more room for opinions to differ.

Our empirical analysis focuses on the relation between stock prices and trading volume. When short-sales of assets are constrained, heterogeneous beliefs create a speculative motive for investors. An asset owner expects not only to collect future cash flows from the asset, but also to profit from other investors' over-optimism in the future by selling the share at a price higher than he thinks it is worth. Thus, the price of an asset can be decomposed in two components: the fundamental valuation of the asset owner if forced to hold the asset forever and collect all the future cashflows, and a speculative component generated by the asset owner's option to sell the share for a speculative profit.

\footnotetext{
${ }^{3}$ Daniel, Hirshleifer, and Teoh (2002) and Barberis and Thaler (2003) review the related psychological evidence and discuss implications of overconfidence to financial markets. Heterogeneous beliefs could also come from other sources. For example, Morris (1996) generates heterogeneous beliefs by removing the common prior assumption.
} 
The magnitude of the speculative component is positively related to the frequency of trades. Scheinkman and Xiong (2003) offer a continuous-time model that produces this relationship. They show that the resale option, analogous to standard financial options but with the difference in investors' beliefs as the underlying asset, is valuable to the asset owner even if other investors' beliefs are currently lower. In particular, the valuation of the resale option depends crucially on the volatility of the difference in beliefs, which increases with investor overconfidence and the fundamental volatility of the asset. As the difference in investors' beliefs become more volatile, the resale option becomes more valuable, and at the same time investors trade more frequently with each other. Hence we have the following hypothesis:

Hypothesis 1: When investors have heterogeneous beliefs about asset fundamentals and are constrained from short-selling shares, there is a positive relationship between the speculative component in asset prices and the turnover of shares.

We will use the pairs of A- and B-shares in China's stock markets to measure the speculative component in prices and examine its relationship to turnover, as highlighted in Hypothesis 1.

We will also examine the relation between share turnover and asset float, i.e., the value of shares that are available for trading in the market. When investors are risk averse and not fully diversified, a larger asset float means that it takes a greater divergence in opinion in the future for asset owners to resell all their shares for a speculative profit, which implies that the resale option is less valuable today. Indeed, Hong, Scheinkman and Xiong (2004) provide a model to show that, as the asset float increases, the "strike price" of the resale option increases. As a result, the resale option becomes less valuable, and the share turnover rate becomes smaller since asset owners are less likely to exercise their resale option. Thus, we have the following hypothesis:

Hypothesis 2: When investors have heterogeneous beliefs about asset fundamentals, are risk averse, and constrained from short-selling shares, the speculative component in 
share prices and the share turnover rate decrease with asset float.

Another determining factor in the relationship between asset prices and share turnover is liquidity. Investors often need to trade assets for portfolio rebalancing or other liquidity reasons, and assets differ in transaction cost and the level of difficulty in matching buyers with sellers. Duffie, Garleanu and Pedersen (2003), Vayanos and Wang (2003) and Weill (2003) provide theoretical models to analyze the effects of liquidity on asset prices and trading volume, based on a search process between buyers and sellers. It is intuitive that liquid assets tend to have higher prices and larger turnover rates. These models also predict that share turnover is positively related to asset float when investors trade for liquidity reasons, opposite to the prediction in Hypothesis 2. The basic argument is that when asset float becomes larger, it is easier for a seller to match with a buyer. Hence a liquidity story implies:

Hypothesis 3: When investors trade for purely liquidity reasons, the turnover rate of shares increases with asset float.

Hence a finding that turnover is positively related to asset float is consistent with the speculative motive but inconsistent with purely liquidity reasons.

\section{The Institutional Background}

\subsection{The Market}

The Chinese stock market is relatively young, dominated by inexperienced individual investors. The two stock exchanges in Shanghai and Shenzhen were established in 1990. These exchanges listed shares of partially privatized state owned enterprises. The market had grown quickly - by 2001 each exchange listed more than 500 companies and the total market cap of Chinese stocks exceeded US $\$ 500$ billion. The number of shareholders increased 160 times, from 400,000 in 1991 to more than 64 million in 2001.

The Chinese market displayed remarkable booms and busts, similar to the U.S. technology stocks in late nineties. Figure 1 illustrates the behavior of the Shanghai A-share 
and B-share indices. Beginning in 1991, the Shanghai A-share index went from 100 to 250 in less than a year and then reached 1200 by the first quarter of 1992. Starting in June 1992, the Shanghai index dropped by more than 60 percent in a period of five months. Within a few days of hitting bottom, the bull market returned. In just three months, the overall market index rose from 400 to a new height of 1600 . However, by the mid 1994 the index was back to 400. In the second half of the decade the market generally trended up, but as it can be seen from the figure, there were numerous episodes in which the index lost several hundred points in a short period. For example, during the 1993-2001 period, there were 20 "mini-crashes" when the Shanghai A-share market Index lost more than $10 \%$ in a month, but only 8 similar episodes in the Nasdaq.

Like the technology stocks in the U.S., the Chinese stock market had very high turnover. From 1991 to 2001, class A shares turned over on average at an annual rate of $500 \%$, which is even higher than the $365 \%$ turnover of DotCom firms in their heyday (Ofek and Richardson, 2001), and more than five times the turnover rate of a typical NYSE stock.

The heavy turnover rate of A shares is puzzling from the perspective of standard models of asset trading, especially given the high transactions cost in Chinese stock markets. During most 1990s, each side of a trade on the Shanghai Stock Exchange had to pay a $0.4 \%$ commission fee to the broker and a $0.3 \%$ stamp tax to the government. ${ }^{4}$ Thus, a trade would incur a total fee of $1.4 \%$ of the proceeds, in addition to other costs such as the price impact of trades. A turnover rate of $500 \%$ a year implies that $7 \%$ of the A-share market capitalization was paid as direct trading fees each year. This number is hard to justify from the usual hedging or portfolio rebalancing arguments. ${ }^{5}$

There are several features of the Chinese market during this period that make it

\footnotetext{
${ }^{4}$ See the official website of Shanghai Stock Exchange: http://www.sse.com.cn.

${ }^{5}$ The trading activity in the Chinese markets is much heavier than the neighboring markets. For example, the average turnover rates in 1994 and 1995 for Indonesia, Japan, and Korea are 23\%, 24\%, and 125\%, respectively, according to Morgan Stanley International Portfolio Desk, IFC Stock Market Factbook (1996) and Dow Jones Research. The direct transaction costs per round-trip trade for Indonesia, Japan, and Korea are 1.6\%, 0.7\%, and $1.3 \%$ respectively.
} 
particularly suited for testing the joint effects of short-sales constraints and heterogeneous beliefs.

Chinese residents face a very stringent "short-sale" constraint. Chinese investors' accounts are kept centrally at the stock exchanges, and it is illegal to sell short. An exchange's computer always checks an investor's position before it executes a trade. This trading system makes it very difficult for financial institutions to lend stocks to their clients for short selling purposes. Moreover, there are no futures or option markets on stocks in China. ${ }^{6}$

Normally, when equity prices exceed their fundamental values, companies will increase the supply of equities to arbitrage the difference. Baker and Wurgler (2002) present strong evidence of market timing by U.S. firms, showing that firms tend to issue equity when their market value is high. This automatic market correction mechanism is impaired in China because of the tight government control over IPOs and seasoned equity offerings (SEOs). Chinese companies need government approval to sell their equity. The process is highly political and companies often have to wait years for issuing shares. Strict quotas, which generally bind, stop many qualifying companies from taking advantage of favorable market conditions to sell their shares. Similarly, when equity prices fall below their fundamental values, companies are also prevented from share buy-backs due to restrictive Chinese corporate law. ${ }^{7}$

Stock trading was also new to most domestic participants. The Chinese stock market only resumed its operation in early 1990s after being shut down for nearly half a century. In our sample period, it was dominated by individual investors. Investment

\footnotetext{
${ }^{6}$ The government banned bond futures market in 1994 because of a price manipulation scandal and has also put the development of equity derivatives markets on hold. So far, no equity derivatives have be legally traded in China due to a lack of government approval.

${ }^{7}$ It is worth noting that, while Chinese firms had almost no control over their IPO or SEO process, the Chinese government does tend to issue more shares in a booming market. However, the issuance is often based on a long waiting list whose order seems to be more related to politics than to relative valuations in the market place. As a result, while the new issues approved by the government may take advantage of overall market conditions, they are not meant to address relative mis-valuations in the marketplace. As late as 2002, a World Bank Report states "...future decisions about which companies will access the market and when and where they will do so will be based on market principles." (Tenev, Zhang, and Brefort, 2002, page 111. The emphasis is ours.)
} 
institutions such as mutual funds and pension funds were still in an early stage of development. According to a recent report of the World Bank "at the end of 1999, of the 30 percent of tradable shares, individuals held 25 percent and institutions held 5 percent" (Tenev, Zhang, and Brefort, 2002, page 77). Feng and Seasholes (2003) summarize the demographic information of a sample of 90,478 actively investing individuals in China, and find that these individuals are much younger, and would have less investing/trading experience when compared to a typical individual investor in U.S.

Given the lack of experience of a typical Chinese investor, it is reasonable to hypothesize that Chinese investors would often disagree about stock valuation and as a result would involve in intensive speculative trading, just as many individual U.S. investors speculated in internet stocks in late nineties. ${ }^{8}$ In the presence of strict short-sales constraints and less experienced individual investors, the mechanism described in Section 2 seems well suited, and we proceed to test its implications.

\subsection{Twin Shares}

A unique feature of the Chinese market is that several dozen companies issued "twin" shares - two classes of common shares with identical voting and dividend rights, listed on the same exchanges (Shanghai or Shenzhen stock exchanges), but traded by different participants. Class A shares were restricted to domestic residents. Class B shares were confined to foreigners before February 2001 when domestic residents were allowed to purchase B shares using foreign currency. Even after the rule change, capital controls continue to serve as a restriction for Chinese residents to acquire B shares. In the period 1993-2001, 75 companies had both class A and class B shares.

Our sample covers prices and other characteristics for all firms that listed both A and B shares from 1993-2001. The data include daily closing prices, monthly returns (with

\footnotetext{
${ }^{8}$ There are also psychological experiments indicating that overconfidence is more pronounced in the face of more difficult tasks (Lichtenstein, Fischhoff, and Phillips, 1982). This evidence again motivates our hypothesis that Chinese investors were more likely to display overconfidence and therefore be involved in speculative trading, especially relative to the foreign institutional investors who invested in the Chinese B-share markets.
} 
dividend reinvested), annual dividends and earnings per share, turnover, and the number of floating shares. ${ }^{9}$ Our sample period of 1993 to 2001 covers the market slump from 1993-1995, a bull market in 1996-1997 and a stock boom from 1999-2001. There is also the important regime change in February 2001, when the Chinese government changed the regulations on B-shares, allowing domestic investors to legally own and trade them if they have foreign currency.

Table 1 provides some simple comparison between A and B shares. The comparison is based on matching $\mathrm{A}$ and $\mathrm{B}$ shares of the same companies in the sample. While there were about 1250 firms on the two exchanges, only 75 firms issued both A and B shares. It is worth noting that the issuance of both shares are usually not determined by the firm, but by central government policies. A shares were more actively traded than B shares. A shares turned over on average at a monthly rate of $47.4 \%$, which is equivalent to an annual rate of $569 \%$. A-share turnover rate is four times that of $\mathrm{B}$ shares $(10.7 \%$ per month or $128 \%$ per year) during the sample period. There was also more cross-sectional variation of turnover in A shares than in B shares. The average cross-sectional variation of monthly turnover in A shares was $18.5 \%$ compared to $5.3 \%$ for B shares.

Table 1 also provides some simple statistics on the A-share price premium over the corresponding B share. On average, A shares fetched a $421.8 \%$ premium over B shares, even though they were entitled to the same legal rights and claim to dividends. ${ }^{10}$ The presence of such a large domestic share premium is quite different from many other emerging and developed markets where domestic shares generally sell at a discount. Hietala (1989), Bailey and Jagtiani (1994), and Stulz and Wasserfallen (1993) have found a price discount for domestic shares in Finland, Thailand and Switzerland. Typically in

\footnotetext{
${ }^{9}$ The data are obtained from Shenzhen GTA Information Technology Inc., which has recently reached an cooperative agreement with Wharton Research Data Service (WRDS) to incorporate GTA research databases on China's security markets into the WRDS. We have also confirmed part of our data from GTA with the data that we received from another source, Boshi Fund Management Company.

${ }^{10}$ Since B shares were traded in dollars and A shares in Yuans, the difference depends on the exchange rate. We used the official rate of the Bank of China. A black market rate would lower the average premium, but would not affect the cross sectional results that we emphasize. In fact, according to Reinhart and Rogoff (2002), the premium in the black market rate was in single digits during the period 1994-2001.
} 
these countries a class of restricted shares is offered to local investors only, and another class of unrestricted shares are offered to both local and foreign investors. The restricted local shares usually sell at a discount. However, both China's A and B shares are restricted shares especially before the B shares were opened to local investors in February 2001. Even after February 2001, Chinese capital controls still imposed restrictions on the ownership of B shares by local investors.

Figure 2 presents a graphic plot of the equally weighted average A shares premium over time. The premium rose from 300\% in April 1993 to about 800\% in March 1999 and then fell to $100 \%$ at the end of 2001. The relaxation of restrictions on purchase of B shares by domestic investors in February 2001 did not eliminate all premia and it remained at a level around $80 \%$, since domestic Chinese investors have limited access to the necessary foreign currency. ${ }^{11}$ Figure 2 also provides the number of firms used in our study of A-B premia. This number changes over time because of listings and de-listings, and grows from less than 10 to over 70 in the sample period.

In addition to their large magnitude, the A-B share premia also vary dramatically across firms. The average (over time) cross-sectional standard deviation of the premia is $167 \%$. This compares with a (time-series) standard deviation of the average monthly premium of $193 \%$ during the same period. Figure 3 plots the cross-sectional standard deviation of price premia over time. It fluctuates from $50 \%$ to over $400 \%$. In the empirical analysis that follows, we focus on explaining the cross-sectional variation of the premia based on A-share investors' speculative motive.

\section{Empirical Analysis}

Could the existence of a speculative component help explain the large variation of premia on A shares? In this section, we test this view. We analyze the cross-sectional association

\footnotetext{
${ }^{11}$ The only legal source of foreign currency for domestic investors is remittance from overseas. Recently, the government has somewhat relaxed its currency control, allowing people to exchange limited amount of foreign currency for overseas travel.
} 
between the A-B share premium, share turnover rate, and asset float as discussed in Section 2. We also introduce several controls, including firms' risk characteristics and measures of liquidity. In addition, we present results from a panel regression that controls for firm and time fixed effects.

\subsection{Speculative Trading and Cross-sectional Variation of A-B Share Premia}

As argued in Section 2, the A-share price of a firm (the i-th firm), $P_{i}^{A}$, can be decomposed as the sum of two components, a fundamental component and a speculative component. The fundamental component is the current expected value of discounted future dividends adjusted for risk premium and we assume that, in analogy to Gordon's Growth Formula, it can be written as $\frac{E_{i}}{R_{i t}^{A}-g_{i}}$, where $E_{i}$ is the expectation of current (unobservable) earnings, $g_{i}$ its growth rate and $R_{i t}^{A}$ the discount rate that applies. Hence the firm's A-share price is

$$
P_{i t}^{A}=\frac{E_{i}}{R_{i t}^{A}-g_{i}}+S_{i t}^{A}
$$

where $S_{i t}^{A}$ is the speculative component in the price of the firm's A share. This component depends on the volatility of the difference in beliefs among the Chinese investors about the firm's fundamental value and on the float of the firm's A shares, among other variables.

In turn, the discount rate is given by,

$$
R_{i t}^{A}=r_{C h i n a, t}+\mu_{i}^{A}
$$

where $r_{C h i n a, t}$ is the domestic interest rate available to Chinese investors and $\mu_{i}^{A}$ is the risk premium which could be determined by the firm's risk characteristics.

Similarly, the B-share price of the firm, which is traded by foreign investors, can be written as

$$
P_{i t}^{B}=\frac{E_{i}}{R_{i t}^{B}-g_{i}}+S_{i t}^{B},
$$

where $S_{i t}^{B}$ is the speculative component in the B-share market. This speculative component in B-shares is positive if foreign investors also display heterogeneous beliefs about 
the fundamental value of the firm. In this case, $S_{i t}^{B}$ depends on the volatility of the difference in beliefs among the foreign investors, and on the float of B-shares. The discount rate $R_{i t}^{B}$ is given by

$$
R_{i t}^{B}=r_{W o r l d, t}+\mu_{i}^{B}
$$

with $r_{W o r l d, t}$ as the world interest rate and $\mu_{i}^{B}$ as the risk premium, which should be influenced by the firm's risk profile and China's sovereign risk premium.

For simplicity, we will assume first that the B-share price provides a reasonable measure of the fundamental component of the firm value, that is $S_{i t}^{B}=0$. Later we will treat the case when $S_{i t}^{B}>0$. Thus, a firm's A and B share premium can be expressed as

$$
\rho_{i t}=\frac{P_{i t}^{A}-P_{i t}^{B}}{P_{i t}^{B}}=\frac{R_{i t}^{B}-g_{i}}{R_{i t}^{A}-g_{i}}+\frac{S_{i t}^{A}}{P_{i t}^{B}}-1 .
$$

If we ignore the difference in the discount rates for A and B shares, then

$$
\rho_{i t} \propto \frac{S_{i t}^{A}}{P_{i t}^{B}} .
$$

We start with this simplification, although we will bring back later the term involving the difference in discount rates.

Hypothesis 1 in Section 2 claims that, as the volatility of the difference in beliefs of the domestic investors who trade a firm's A shares changes, the speculative component $S_{i t}^{A}$ and the turnover rate of $\mathrm{A}$ shares move in the same direction. There are several reasons why the volatility of the difference in investors' beliefs would vary across stocks. First, since the A-share markets are dominated by individual investors, each stock is likely to have a different investor base at a given point of time. Second, individuals could display different degrees of overconfidence with respect to information related to individual stocks. Finally, assets may also differ in the amount of fundamental uncertainty that creates room for investors' beliefs to diverge. Thus, we predict a positive association between the A-B share premium and the A-share turnover rate. 
Since turnover rates are highly persistent over time and it is difficult to remove this persistence (Lo and Wang, 2000), we focus on explaining the cross-sectional variation of A-B share premia. To examine this correlation, we run the following cross-sectional regression of end-of-month A-B premia on monthly average turnover rates:

$$
\rho_{i t}=c_{0 t}+c_{1 t} \tau_{i t}^{A}+c_{2 t} \tau_{i t}^{B}+\epsilon_{i t}
$$

where $\tau_{i t}^{A}=\log \left(1+\right.$ turnover $\left._{i t}^{A}\right)$ and $\tau_{i t}^{B}=\log \left(1+\right.$ turnover $\left._{i t}^{B}\right)$. Here, we expect the coefficient $c_{1 t}$ to be positive. We incorporate the turnover of $\mathrm{B}$ shares in the regression, since it is possible that a speculative component may also exist in B shares $\left(S_{i t}^{B}>0\right)$. If this is the case, we expect a positive relationship between $S_{i t}^{B}$ and $\tau_{i t}^{B}$ since both are generated by heterogeneous beliefs among the foreign investors who trade the firm's B shares, and the coefficient $c_{2 t}$ should be negative.

The results of this regression are reported in Table $2 .{ }^{12}$ In the period that precedes the liberalization of B-shares trading to domestic investors and that is covered by our data, April 1993 to December 2000, A- and B-share turnover explain on average 25\% of the cross-sectional variation in A-B share premium. The average $c_{1 t}$, the coefficient on A-share turnover, is positive and significant with a Fama-MacBeth t-statistics of $6.7,{ }^{13}$ and A-share turnover explains $20 \%$ of the cross sectional variation of the premium. A $5 \%$ increase in A-share turnover is associated with an increase in excess of $21 \%$ of a stock's A-B premium. The coefficient of B-share turnover, $c_{2 t}$, is not statistically significant. ${ }^{14}$ The positive and significant effect of A-share turnover on A-B premium supports our main hypothesis that A-share investors' speculative motive contributed a speculative component to A-share prices. Figure 3 illustrates how the time series variation of the (cross-sectional) standard deviation of the premia is explained by the turnover rates of

\footnotetext{
${ }^{12}$ Since high turnover and high prices are often observed immediately after IPOs, we only include firms in our panel one year after their IPOs.

${ }^{13}$ The Fama-MacBeth t-stat is computed by the average of the coefficients divided by the modified standard error calculated as in Petersen (2005) to control for different sample sizes.

${ }^{14}$ Although the point estimate is positive it is not significant at conventional levels. Furthermore the panel regressions that appear below yield a negative and significant estimate.
} 
A and B shares.

\subsection{Controlling for Liquidity}

It may be argued that the relation between A-share turnover and A-B premium is related to market liquidity of A shares. ${ }^{15}$ If a firm's A shares are relatively more liquid, investors will trade more and may be willing to pay more for these shares, because of the smaller transaction cost. As such, cross-sectional difference in liquidity could also generate a positive relationship between A-share turnover and A-B premium.

In reality, liquidity is unlikely to explain much of the the cross-sectional variation of A-share prices. As discussed earlier, A-share markets were dominated by individual investors. Domestic investment institutions such as mutual funds and pension funds were not fully developed. The observed turnover and the likely demand by individual investors indicate that liquidity was not a problem. On the other hand, liquidity might have been a problem for foreign institutions who invested in the B-share markets.

Nonetheless, we control for the effects of liquidity in the A-B share premia, using the proportion of no-price-change days of a stock over a month as a measure of liquidity. Lesmond, Ogden, and Trzcinka (1999) use this variable to measure liquidity for NYSE stocks, and find that it is highly correlated with other liquidity estimators such as quoted bid-ask spread and Roll's measure of the effective spread. Recently, Bekaert, Harvey, and Lundblad (2003) suggest that this measure is particularly useful in emerging markets where direct measures of trading cost such as bid-ask spreads are usually not available. They find that the fraction of no-price-change days is significant in explaining expected stock returns using data of 19 developing countries (China not included). On the other hand, they find that share turnover rates are not significant.

We obtained daily return data for the period 1995-2001. Table 1 shows that A shares

\footnotetext{
${ }^{15}$ Liquidity is an important factor in explaining cross-sectional differences in stock prices and stock returns. For example, see Amihud and Mendelson (1986), and Pastor and Stambaugh (2003) for U.S. stock prices and returns, Bekaert, Harvey, and Lundblad (2003) for emerging market stock returns, and Chen and Xiong (2002) for prices of Chinese non-tradable shares.
} 
averaged only $2.1 \%$ of trading days with no price changes in this period, while the corresponding B shares averaged $14.3 \%$. This suggests that B shares are more illiquid than A shares.

Panel A of Table 3 reports the cross-sectional regression of A-B share premium on the turnover rates of A-shares and B-shares, and the corresponding proportion of noprice-change days, denoted by $z_{i t}^{A}$ and $z_{i t}^{B}$, for the period 1995-2000 that precedes the liberalization of B-shares. A comparison with Table 2 shows that using our control for liquidity does not change much the coefficients of A-share and B-share turnover rates. This is an indication that the effects of turnover rates of the A shares on A-B share premium does not result from the demand for liquidity.

The proportion of no-price-change days of $\mathrm{B}$ shares has a significant and positive effect on the A-B share premium. This indicates that liquidity is relevant for B-share prices and is consistent with the results in Bekaert, Harvey, and Lundblad (2003) for other emerging markets. The proportion of no-price-change days in A-shares is not statistically significant for the determination of the A-B premia. This agrees with our earlier argument that illiquidity in A markets is not important. Panel B of Table 3

provides similar results by regressing A-B share premium on $z_{i t}^{A}$ and $z_{i t}^{B}$ only. Dropping the turnover variables does not change much the point estimates of the no-trade days coefficients.

\subsection{Effects of Asset Float on Turnover}

To further differentiate the effects of speculative trading and liquidity reasons, we examine the relation between the turnover rate of shares and asset float in both A-share markets and B-share markets.

Hypothesis 2 in Section 2 suggests that share turnover generated by investors' speculative motive decreases with asset float. This is because when investors are risk averse, a larger asset float implies that it takes a greater divergence in beliefs for asset owners 
to resell their shares at a given price in the future. ${ }^{16}$

On the other hand, hypothesis 3 suggests that share turnover is positively related to asset float if liquidity reasons are important. As float increases, it is easier for buyers to match with sellers, thus causing the turnover rate to increase. ${ }^{17}$

We examine the effect of float on A-share turnover by running the following crosssectional regression:

$$
\tau_{i t}^{A}=\alpha_{0 t}+\alpha_{1 t} \log \left(\text { Float }_{i, t-1}^{A}\right)+\epsilon_{i t}
$$

The float is measured by the market valuation of all publicly available shares. The results are shown in Table 4 for the period April 1993 to December 2000. Panel A shows that a firm's A-share turnover decreases with its float, which is consistent with hypothesis 2 , and the coefficient is significant.

A corresponding regression is conducted for B-share turnover and is reported in Panel B. It indicates that, in the same period, a firm's B-share turnover increases with its own float, and that the coefficient is also significant. The positive relation between B-share turnover and B-share float is consistent with a liquidity story, as opposed to a purely speculative trading theory. B shares are usually less liquid than A shares. When a firm's B-share float becomes larger, more foreign investors (especially foreign institutions) will be interested in trading in this share, and liquidity improves. As a result, shares are turned over faster. The different nature of A-share and B-share turnover is consistent with our earlier result that speculative trading is important for A-share prices but liquidity is important for B-share prices.

\footnotetext{
${ }^{16}$ Such a prediction is consistent with the observation by Ofek and Richardson (2003) on the U.S. technology bubble. The turnover rates of internet stocks dried up after a dramatic expansion in the float of shares in the spring of 2000, due to insiders' selling after the expiration of lock-ups.

${ }^{17} \mathrm{~A}$ positive correlation between share turnover and asset float is supported by empirical analysis on liquidity trading. For example, Amihud and Mendelson (1991) attribute the difference in the liquidity between on-the-run treasury bonds and off-the-run bonds to the holding of off-the-run bonds by entities such as insurance companies that typically do not trade. Chordia, Subrahmanyam and Anshuman (2001) provide evidence of a positive link between firm size, liquidity and turnover in U.S. stocks.
} 


\subsection{Other Determinants of A-B Share Premia}

Besides speculation and liquidity, the A-B share premia should also be driven by differential demand curves of domestic and foreign investors, or equivalently different risks on a firm's returns. To control for these effects, we incorporate various risk measures ${ }^{18}$ of both $\mathrm{A}$-shares and $\mathrm{B}$-shares into the cross-sectional regression for A-B premia:

$$
\begin{aligned}
\rho_{i t}=c_{0 t} & +c_{1 t} \tau_{i t}^{A}+c_{2 t} \tau_{i t}^{B}+c_{3 t} \operatorname{Cov}\left(R_{B i}, R_{F}\right)+c_{4 t} \operatorname{Cov}\left(R_{B i}, R_{B}\right) \\
& +c_{5 t} \operatorname{Cov}\left(R_{A i}, R_{A}\right)+c_{6 t} \operatorname{Var}\left(R_{A i}\right)+\epsilon_{i t} .
\end{aligned}
$$

The covariances of a firm's B share returns with the Morgan Stanley world return index, $R_{F}$, and China's B-share return index, $R_{B}$, are measures of risk in B-share markets. We measure systematic risk and firm specific risk in A-share markets by the covariance between a firm's A-share returns and China's A-share return index, $\operatorname{Cov}\left(R_{A i}, R_{A}\right)$, and the variance of the firm's A-share returns, $\operatorname{Var}\left(R_{A i}\right)$.

The regression results are reported in Table 5 for the period April 1993 to December 2000. A-share turnover is still highly significant with a t-stat of 5.9, and it explains $15.5 \%$ of the cross-sectional variations in A-B share premium. Furthermore, the impact of a one standard deviation of A-share turnover has at least five times the impact of a one standard deviation of any of the four risk measures.

\subsection{Panel Regressions}

The Fama-MacBeth estimates do not account for firm specific effects, and this may result in an underestimation of standard errors (Petersen, 2005.) As a further robustness check, we use a panel regression approach that includes firm and time effects. The following parsimonious form is employed:

$$
\rho_{i t}=u_{i}+c_{0 t}+c_{1} \tau_{i t}^{A}+c_{2} \tau_{i t}^{B}+\epsilon_{i t}
$$

\footnotetext{
${ }^{18}$ These risk measures were the ones used by Eun, Janakiramanan and Lee (2001).
} 
The terms $u_{i}$ and $c_{0 t}$ come from linearizing the term $\frac{R_{i t}^{B}-g_{i}}{R_{i t}^{A}-g_{i}}$ in equation (1). The $u_{i} \mathrm{~s}$ deal with cross-sectional differences in firms' characteristics and the $c_{0 t}$ s time-series variables such as Chinese and world interest rates, equity premia and China's political risks.

Table 6 summarizes the estimates. For the model described by equation (4), the panel regression estimate of the coefficient of A-share turnover is about half of the FamaMacBeth regression estimate in Table 2, but still highly significant with a t-stat exceeding 16. Our point estimate of the coefficient of B-share turnover is now negative and significant. This suggests either the existence of a speculative component in B shares or the presence of time-varying firm specific liquidity. Since, unless there are omitted variables, a random effects estimate would yield gains in efficiency, we also present the (almost identical) results of a random firm effects model, that assumes that firm effects are uncorrelated cross-sectionally. A specification test described by Hausman (1978) ${ }^{19}$ fails to reject this restriction. ${ }^{20}$

Equation (1) suggests that the time effect term, $c_{0 t}$, incorporates the effects of variables such as Chinese interest rates, world interest rates, and the risk premium from China's political risk. ${ }^{21}$ For this reason, we examine the following specification for the time effect coefficient:

$$
c_{0 t}=\vartheta_{0}+\vartheta_{1} r_{\text {China }}+\vartheta_{2} r_{\text {World }}+\vartheta_{3} i_{\text {ChinaSprd }}+\epsilon_{t} .
$$

Intuitively, an increase in Chinese interest rates should lower the A-share prices, and we should expect $\vartheta_{1}$ to be negative. Similarly an increase in world interest rates should lower B-share prices, predicting a positive $\vartheta_{2}$. Here we use the Chinese three-month deposit rate to proxy for Chinese risk free rate $r_{C h i n a}$ and US three-month Treasury bill rate for world interest rate $r_{W o r l d}$. Moreover, an increase in China's political/sovereign

\footnotetext{
${ }^{19}$ See also $\mathrm{Wu}(1973)$.

${ }^{20}$ We also conducted several other robustness checks for which we do not report detailed estimates. For instance, the Hausman test rejects a model with random time effects. In addition, both a Durbin-Watson test, as modified by Bhargava et al. (1982), and a Baltagi-Wu (1999) test fail to reject the hypothesis that the errors in our panel estimates are independent across time.

${ }^{21}$ Since ex-ante risk premia are difficult to measure, we ignore the Chinese and world market equity risk premia.
} 
risk, which we proxy by using the spread between Chinese long-term bond and US 10-year bond $\left(i_{\text {Chinasprd }}\right)$, should also lower B-share prices, yielding a positive $\vartheta_{3}{ }^{22}$

Table 7 presents the results for the time period February 1994-December 2000, ${ }^{23}$ using $c_{0 t}$ estimated from specification I of our panel regression. The $R^{2}$ is $85 \%, \vartheta_{1}$ and $\vartheta_{3}$ have the right signs and are highly significant, while $\vartheta_{2}$ has the right sign but is not statistically significant. Hence the time effect is well described by a combination of Chinese interest rates, world interest rates and a measure of the political risks, and each of these variables contributes with the expected sign, as consistent with the finding of Fernald and Rogers (2002). While our results from the panel regressions support the importance of the discount rates and political risk in explaining the A-B share premium, they also demonstrate that the effect of A-share turnover still holds even after controlling for these other variables.

\section{A Natural Experiment}

On February 28, 2001, the Chinese government opened the markets for B shares to domestic investors, provided they used foreign currency. Here we examine whether the relationship among A-B share premium, share turnover and asset float changed after the regulatory shift. ${ }^{24}$

Table 8 reports the market reaction to the changes. Panel A shows that from February 16, 2001 to March 9, 2001, A-share prices decreased on average 0.5\%, and the drop is statistically insignificant, with a standard deviation of $22 \%$. On the other hand, B-share prices increased $63 \%$ on average and the increase is significant with a standard deviation of only $7.3 \%$. Therefore, most price reaction came from B shares. Panel B shows the change in $\mathrm{B}$ share turnover rates around the change in regulation. Before the event, $\mathrm{B}$ shares have an average monthly turnover of $12.3 \%$, while post-event it becomes $44.4 \%$,

\footnotetext{
${ }^{22}$ Kim and Mei (2001) show that China's political risk negatively affects stock prices in Hong Kong.

${ }^{23}$ Our sample here is shorter, since the Chinese Long-term bond data starts on February 1994.

${ }^{24}$ Karolyi and Li (2003) and Chan, Menkveld and Yang (2003) also study this rule change. Their focus is on the effects of liquidity and information asymmetry on the A-B share premium.
} 
which is similar to the A-share turnover rate reported in Table 1. These observations indicate that after allowing Chinese domestic investors to buy B shares, these shares behaved more like A shares, turning over faster and with higher prices.

To further investigate the behavior of B-share markets after February 2001, we repeat the cross-sectional regression of Tables 2 and 3 (regressing A-B premium to A-share and B-share turnover) for the period of March 2001 to December 2001. The results are reported in Part I of Table 9. The coefficient of A-share turnover is still positive and significant, while the coefficient of B-share turnover becomes negative and significant, in contrast to the results for the earlier period shown in Tables 2 and 3. This suggests that a speculative component might have appeared in B-share prices after the rule change. These results remain unchanged after we control for liquidity using the proportion of noprice-change days. In addition, we note that the coefficient of B-share liquidity becomes insignificant, in contrast to the positive and significant result for the earlier period. This indicates that liquidity may no longer be a main determinant of B-share prices after the increase in trading volume that followed the liberalization.

Part II of Table 9 repeats the same cross-sectional regression in Table 4 (regressing A and B-share turnover rates on their float) after the rule change. This time, while the Ashare coefficient remains negative, the B share coefficient turns negative and significant, which is the opposite of the positive coefficient found for the period before the event as shown in Table $4 .{ }^{25}$ A negative association between turnover and float suggests that after the opening of B-shares markets to local investors, trading in B-share markets is driven more by speculation than by liquidity reasons.

Overall, our analysis of the 2001 relaxation of B-share restrictions shows that while A-share markets were barely affected, B-share prices and turnover rates went up dramatically, indicating that speculation by domestic investors may have become an important

\footnotetext{
${ }^{25}$ To see whether there is a significant coefficient change post liberalization, Table 9 also provides a simple t-test by comparing the mean coefficient estimates post liberalization to the corresponding mean estimates before liberalization. The results in Part II show that while the coefficient change in A share float is insignificant, the coefficient change in B share float is highly significant.
} 
factor in B-share markets after the entrance of domestic investors.

\section{Conclusion}

We analyze a data sample from a market with perfectly segmented dual-class shares to test implications from the presence of short-sales constraints and heterogeneous beliefs on asset prices and trading volume. Using the prices of the foreign shares to control for variations in firms' fundamentals, we find several results consistent with the existence of a speculative component in the prices of domestic shares. First, the price difference between a firm's domestic and foreign shares is positively related to the turnover rate of the domestic share. Second, this positive association still holds after controlling for several alternative effects, such as liquidity, risk premium, and discount rates. Third, the turnover rate of domestic shares decreases with their float. We also provide further evidence through an analysis of a policy shift.

In many aspects, the price dynamics of the newly emerged Chinese market resembled the technology bubble in the U.S. Our paper, using an entirely different data source, confirms that investors' speculative trading is an important determinant of stock prices during bubbles, e.g., Cochrane (2003), Lamont and Thaler (2003) and Ofek and Richardson (2003). 


\section{References}

[1] Amihud, Y. and H. Mendelson, 1986, Asset Pricing and the Bid-Ask Spread, Journal of Financial Economics 17, 223-249.

[2] Amihud, Y. and H. Mendelson, 1991, Liquidity, Maturity, and the Yields on the U.S. Treasury Securities, Journal of Finance 46, 1411-1425.

[3] Bailey, W., and J. Jagtiani, 1994, Foreign Ownership Restrictions and Stock Prices in the Thai Capital Market, Journal of Financial Economics 36, 57-87

[4] Baker, M. and J. Wurgler, 2002, Market Timing and Capital Structure, Journal of Finance $57,1-32$.

[5] Baltagi, B. and P. Wu, 1999, Unequally Spaced Panel Data Regressions with AR (1) Disturbances, Econometric Theory 15, 814-823.

[6] Barberis, N. and R. Thaler, 2003, A Survey of Behavioral Finance, in Handbook of the Economics of Finance, edited by G. Constantinides, M. Harris and R. Stulz, North-Holland.

[7] Bekaert, G., C. Harvey, and C. Lundblad, 2003, Liquidity and Expected Returns: Lessons from Emerging Markets, Working Paper.

[8] Bhargava, A., L. Franzini, abd W. Narendranathan, 1982, Serial Correlation and the Fixed Effects Model, Review of Economic Studies 49, 533-49.

[9] Chan, K.A., A.J. Menkveld, and Z. Yang, 2003, Evidence on the Foreign Share Discount Puzzle in China: Liquidity or Information Asymmetry? Working Paper.

[10] Chen, J., H. Hong, and J. Stein, 2002, Breadth of Ownership and Stock Returns, Journal of Financial Economics 66, 171-205.

[11] Chen, Z. and P. Xiong, 2002, Discounts on Illiquid Stocks: Evidence from China, Working paper.

[12] Chordia, T., A. Subrahmanyam and V. Anshuman, 2001, Trading Activity and Expected Stock Returns, Journal of Financial Economics 59, 3-32.

[13] Cochrane, John, 2003, Stocks as money: convenience yield and the tech-stock bubble, NBER Working Paper 8987 and in William C. Hunter, George G. Kaufman and Michael Pomerleano, Ed.: Asset Price Bubbles (MIT Press, Cambridge).

[14] Daniel, K., D. Hirshleifer and S. H. Teoh, 2002, Investor Psychology in Capital Markets: Evidence and Policy Implications, Journal of Monetary Economics 49, 139-209.

[15] Diether, K., C. Malloy, and A. Scherbina (2002), Differences of opinion and the cross section of stock returns, Journal of Finance 57, 2113-2141.

[16] Duffie, D., N. Garleanu and L. Pedersen, 2002, Securities Lending, Shorting, and Pricing, Journal of Financial Economics 66, 307-339.

[17] Duffie, D., N. Garleanu and L. Pedersen, 2003, Over-the-Counter Markets, Econometrica, forthcoming.

[18] Eun, C., S. Janakiramanan, and B. Lee, 2001, The Chinese Discount Puzzle, Working Paper. 
[19] Fama, E. and J. MacBeth, 1973, Risk, Return, and Equilibrium: Empirical Tests, Journal of Political Economy 81, 607-636.

[20] Feng, L. and M. Seasholes, 2003, A Profile of Individual Investors in an Emerging Stock Market, Working Paper.

[21] Fernald, J. and J. Rogers, 2002, Puzzles in the Chinese Stock Market, Review of Economics and Statistics 84, 416-432.

[22] Froot, K. and E. Dabora, 1999, How Are Stock Prices Affected by the Location of Trade? Journal of Financial Economics 53, 189-216.

[23] Gao, S., 2002, China Stock Market in a Global Perspective, Research report, Dow Jones.

[24] Greene, W., 2002, Econometric Analysis, Prentice Hall.

[25] Harrison, M. and D. Kreps, 1978, Speculative Investor Behavior in a Stock Market with Heterogeneous Expectations, Quarterly Journal of Economics 92, 323-336.

[26] Hausman, J., 1978, Specification Tests in Econometrics, Econometrica 46, 1251-71.

[27] Hietala, P., 1989. Asset Pricing in Partially Segmented Markets: Evidence from the Finnish Market, Journal of Finance 44, 697-718.

[28] Hong, H., J. Scheinkman, and W. Xiong, 2004, Asset Float and Speculative Bubbles, Journal of Finance, forthcoming.

[29] Jones, C. and O. Lamont, 2002, Short-Sale Constraints and Stock Returns, Journal of Financial Economics 66, 207-239.

[30] Karolyi, A. and L. Li, 2003, A Resolution of the Chinese Discount Puzzle, Working Paper.

[31] Kim, K and J. Mei, 2001, What Makes the Stock Market Jump?-An Analysis of Political Risk on the Hong Kong Stock Returns, Journal of International Money and Finance, 1003-1016.

[32] Lamont, O. and R. Thaler, 2003, Can the Market Add and Subtract? Mispricing in Tech Stock Carve-outs, Journal of Political Economy 111, 227-268.

[33] Lee, C., A. Shleifer and R. Thaler, 1991, Investor Sentiment and the Closed-End Fund Puzzle, Journal of Finance 46, 75-110.

[34] Lesmond, D., J.P. Ogden, and C. Trzcinka, 1999, A New Estimate of Transaction Costs, Review of Financial Studies 12, 1113-1141.

[35] Lichtenstein, S., B. Fischhoff, and L. Phillips, 1982, Calibration of Probabilities: The State of the Art to 1980, in Daniel Kahneman, Paul Slovic, and Amos Tversky, ed.: Judgement under Uncertainty: Heuristics and Biases, Cambridge University Press, Cambridge.

[36] Lo, A., and J. Wang, 2000, Trading Volume: Definitions, Data Analysis, and Implications of Portfolio Theory, Review of Financial Studies, 13, 257-300.

[37] Morris, S., 1996, Speculative Investor Behavior and Learning, Quarterly Journal of Economics 110, 1111-1133.

[38] Ofek, E. and M. Richardson, 2003, Dotcom Mania: The Rise and Fall of Internet Stock Prices, Journal of Finance 58, 1113-1137. 
[39] Pastor, L. and R. Stambaugh, 2003, Liquidity Risk and Expected Stock Returns, Journal of Political Economy 111, 642-685.

[40] Petersen, M., 2005, Estimating Standard Error in Finance Panel Data Sets: Comparing Approaches, NBER Working paper 11280.

[41] Reinhart, C. and K. Rogoff, 2002, The Modern History of Exchange Rate Arrangements: A Reinterpretation, Working paper, IMF.

[42] Scheinkman, J. and W. Xiong, 2003, Overconfidence and Speculative Bubbles, Journal of Political Economy 111, 1183-1219.

[43] Stulz, R.M. and W. Wasserfallen, 1995, Foreign Equity Investment Restrictions and Shareholder Wealth Maximization: Theory and Evidence, Review of Financial Studies, 10191057.

[44] Tenev, S., C. Zhang, and L. Brefort, 2002, Corporate Governance and Enterprise Reform in China, The World Bank and the International Finance Corporation.

[45] Weill, P. 2003, Liquidity Premia in Dynamic Bargaining Markets, Working paper.

[46] Wu, D. M., 1973 Alternative Tests of Independence between Stochastic Regressors and Disturbances, Econometrica 41 (4), 733-750.

[47] Vayanos, D. and T. Wang, 2003, Search and Endogenous Concentration of Liquidity in Asset Markets, Working paper. 


\section{Table 1. Summary Statistics of A-B Pairs}

This table provides summary statistics for all firms that had issued both A-shares and B-shares between April 1993 and December 2001. There were 75 such firms. The share turnover is calculated as the monthly trading volume divided by the number of floating shares, the logarithm of asset float is based on the market value of floating shares, and the premium is defined as the ratio of A-share price over B-share price minus one. These three variables are available for the period April 1993 - December 2001. The fraction of no-price-change days is calculated directly from daily prices for the sample period January 1995 - December 2001. The Cross-sectional STD of a variable is calculated as the time average of cross-sectional standard deviation.

\begin{tabular}{lccccc}
\hline & & $\begin{array}{c}\text { Turnover } \\
\text { (monthly) }\end{array}$ & $\begin{array}{c}\text { Log (asset } \\
\text { float) }\end{array}$ & Premium & $\begin{array}{c}\text { \% of No-price- } \\
\text { change Days }\end{array}$ \\
\hline Mean & A & $47.4 \%$ & 19.63 & $421.8 \%$ & $2.1 \%$ \\
& B & $10.7 \%$ & 19.13 & & $14.3 \%$ \\
Cross-sectional STD & A & $18.5 \%$ & 0.801 & $167.3 \%$ & $3.0 \%$ \\
& B & $5.3 \%$ & 0.909 & & $11.8 \%$ \\
\hline
\end{tabular}




\section{Table 2. Cross-Sectional Regressions of A-B Share Premium (Monthly, April 1993 - December 2000)}

This table presents a summary of the following monthly cross-sectional regressions:

$$
\rho_{i t}=c_{0 t}+c_{1 t} \tau_{i t}^{A}+c_{2 t} \tau_{i t}^{B}+\varepsilon_{i t},
$$

where $\rho_{i t}$ is the A-B share premium for firm $\mathrm{i}$ in month $t, \tau_{i t}^{A}=\log \left(1+\right.$ turnover $\left.{ }_{i t}^{A}\right)$, $\tau_{i t}^{B}=\log \left(1+\right.$ turnover $\left.{ }_{i t}^{B}\right)$. The reported coefficients are the time-series average of monthly estimates, weighted by the number of observations each month. The Fama-MacBeth t-stat is computed by the weighted average of the coefficients divided by the modified standard error as in Petersen (2005) to control for different sample sizes. Average Marginal $\mathrm{R}^{2}$ is the time-series average of marginal $\mathrm{R}^{2}$ of the monthly cross-sectional regressions.

\begin{tabular}{lcccc}
\hline & $\mathrm{c}_{0 \mathrm{t}}$ & $\mathrm{c}_{1 \mathrm{t}}$ & $\mathrm{C}_{2 \mathrm{t}}$ & Average Adj.R $^{2}$ \\
\hline Average Coefficient & 3.777 & 4.259 & 1.731 & 0.255 \\
FM t-Stat & 24.72 & 6.734 & 1.098 & \\
Average Marginal R & - & 0.203 & 0.046 & \\
\hline
\end{tabular}




\section{Table 3. Cross-Sectional Regressions of A-B Share Premium (Monthly, January 1995 - December 2000)}

This table presents a summary of the following monthly cross-sectional regressions:

$$
\rho_{i t}=c_{0 t}+c_{1 t} \tau_{i t}^{A}+c_{2 t} \tau_{i t}^{B}+c_{3 t} z_{i t}^{A}+c_{4 t} z_{i t}^{B}+\varepsilon_{i t}
$$

where $\rho_{i t}$ is the A-B share premium for firm i in month $t, \tau_{i t}^{A}=\log \left(1+\right.$ turnover $\left.{ }_{i t}^{A}\right)$, $\tau_{i t}^{B}=\log \left(1+\right.$ turnover $\left.{ }_{i t}^{B}\right), z_{i t}^{A}$ is the proportion of no-price-change days for the A-shares of firm $\mathrm{i}$ in month $\mathrm{t}$, and $z_{i t}^{B}$ is the proportion of no-price-change days for the B-shares of firm $\mathrm{i}$ in month t. The reported coefficients are the time-series average of monthly estimates, weighted by the number of observations each month. The Fama-MacBeth t-stat is computed by the weighted average of the coefficients divided by the modified standard error as in Petersen (2005) to control for different sample sizes. Average Marginal $\mathrm{R}^{2}$ is the time-series average of marginal $\mathrm{R}^{2}$ of the monthly cross-sectional regressions.

A. Turnover and No-price-change Days

\begin{tabular}{|c|c|c|c|c|c|c|}
\hline & $\mathrm{c}_{0 \mathrm{t}}$ & $\mathrm{C}_{1 \mathrm{t}}$ & $\mathrm{C}_{2 \mathrm{t}}$ & $\mathrm{C}_{3 \mathrm{t}}$ & $\mathrm{C}_{4 \mathrm{t}}$ & Average Adj.R ${ }^{2}$ \\
\hline Average Coefficient & 3.498 & 4.559 & 1.599 & 2.018 & 3.586 & 0.270 \\
\hline FM t-Stat & 22.499 & 6.444 & 1.021 & 1.318 & 6.944 & \\
\hline Average Marginal $\mathrm{R}^{2}$ & - & 0.157 & 0.032 & 0.027 & 0.044 & \\
\hline \multicolumn{7}{|c|}{ B. No-price-change Days Only } \\
\hline & $\mathrm{C}_{0 \mathrm{t}}$ & $\mathrm{C}_{1 \mathrm{t}}$ & $\mathrm{C}_{2 \mathrm{t}}$ & $\mathrm{C}_{3 \mathrm{t}}$ & $\mathrm{C}_{4 \mathrm{t}}$ & Average Adj.R ${ }^{2}$ \\
\hline Average Coefficient & 4.622 & & & 2.215 & 4.557 & 0.091 \\
\hline FM t-Stat & 23.08 & & & 1.376 & 8.091 & \\
\hline Average Marginal $\mathrm{R}^{2}$ & - & & & 0.029 & 0.060 & \\
\hline
\end{tabular}




\section{Table 4. Cross-Sectional Relation between Turnover and Asset Float (Monthly, April 1993 - December 2000)}

This table presents monthly cross-sectional regression of A-share turnover and B-share turnover, $\tau_{i t}^{A}=\log \left(1+\right.$ turnover $\left.{ }_{i t}^{A}\right)$ and $\tau_{i t}^{B}=\log \left(1+\right.$ turnover $\left.{ }_{i t}^{B}\right)$, on the corresponding asset float. Asset float is measured by the market valuation of all floating shares. The reported coefficients are the time-series average of monthly estimates, weighted by the number of observations each month. The Fama-MacBeth t-stat is computed by the weighted average of the coefficients divided by the modified standard error as in Petersen (2005) to control for different sample sizes. Average Marginal $\mathrm{R}^{2}$ is the time-series average of marginal $\mathrm{R}^{2}$ of the monthly cross-sectional regressions.

\section{A. Summary of Cross-Sectional Regressions for A shares}

$$
\tau_{i t}^{A}=\alpha_{0 t}+\alpha_{1 t} \log \left(\text { Float }_{i, t-1}^{A}\right)+\varepsilon_{i t}
$$

\begin{tabular}{lccc}
\hline & $\alpha_{0 \mathrm{t}}$ & $\alpha_{1 \mathrm{t}}$ & Average Adj.R ${ }^{2}$ \\
\hline Average Coeff. & 1.408 & -0.054 & 0.125 \\
FM t-Stat & 7.776 & -5.854 & \\
\hline
\end{tabular}

B. Summary of Cross-Sectional Regressions for B shares

$$
\tau_{i t}^{B}=\alpha_{0 t}+\alpha_{1 t} \log \left(\text { Float }_{i, t-1}^{B}\right)+\varepsilon_{i t}
$$

\begin{tabular}{lccc}
\hline & $\alpha_{0 \mathrm{t}}$ & $\alpha_{1 \mathrm{t}}$ & Average Adj.R $^{2}$ \\
\hline Average Coeff. & 0.001 & 0.003 & 0.067 \\
FM t-Stat & 0.049 & 2.436 & \\
\hline
\end{tabular}




\section{Table 5. Cross-Sectional Regressions of A-B Premium (Monthly, April 1993 - December 2000)}

This table presents a summary of the following monthly cross-sectional regressions:

$\rho_{i t}=c_{0 t}+c_{1 t} \tau_{i t}^{A}+c_{2 t} \tau_{i t}^{B}+c_{3 t} \operatorname{Cov}\left(R_{B i}, R_{F}\right)+c_{4 t} \operatorname{Cov}\left(R_{B i}, R_{B}\right)+c_{5 t} \operatorname{Cov}\left(R_{A i}, R_{A}\right)+c_{6 t} \operatorname{Var}\left(R_{A i}\right)+\varepsilon_{i t}$

where $\rho_{i t}$ is the A-B share premium for firm $\mathrm{i}$ in month $t, \tau_{i t}^{A}=\log \left(1+\right.$ turnover $\left.{ }_{i t}^{A}\right)$, $\tau_{i t}^{B}=\log \left(1+\right.$ turnover $\left._{i t}^{B}\right), \operatorname{Cov}\left(R_{B i}, R_{F}\right)$ is the covariance between a firm's B-share return and the Morgan Stanley world return index, $\operatorname{Cov}\left(R_{B i}, R_{B}\right)$ is the covariance between a firm's Bshare return and the B-share return index, $\operatorname{Cov}\left(R_{A i}, R_{A}\right)$ is the covariance between a firm's Ashare return and the A-share return index, and $\operatorname{Var}\left(R_{A i}\right)$ is the variance of a firm's A-share return. The reported coefficients are the time-series average of monthly estimates, weighted by the number of observations each month. The Fama-MacBeth t-stat is computed by the weighted average of the coefficients divided by the modified standard error as in Petersen (2005) to control for different sample sizes. Average Marginal $\mathrm{R}^{2}$ is the time-series average of marginal $\mathrm{R}^{2}$ of the monthly cross-sectional regressions.

\begin{tabular}{ccccccccc}
\hline & $\mathrm{C}_{0 \mathrm{t}}$ & $\mathrm{C}_{1 \mathrm{t}}$ & $\mathrm{C}_{2 \mathrm{t}}$ & $\mathrm{C}_{3 \mathrm{t}}$ & $\mathrm{C}_{4 \mathrm{t}}$ & $\mathrm{C}_{5 \mathrm{t}}$ & $\mathrm{C}_{6 \mathrm{t}}$ & Average Adj.R $^{2}$ \\
\hline Average Coefficient & 4.136 & 2.642 & 2.426 & 15.597 & -14.16 & 7.039 & 0.045 & 0.263 \\
FM t-Stat & 26.026 & 5.896 & 1.456 & 4.64 & -19.91 & 3.559 & 0.192 & \\
Average Marginal R & & 0.155 & 0.041 & 0.013 & 0.03 & 0.02 & 0.009 & \\
\hline
\end{tabular}




\section{Table 6. Panel Regression of A-B premium (Monthly, April 1993-December 2000)}

This table presents estimates for the following panel regression:

$$
\rho_{i t}=u_{i}+c_{0 t}+c_{1} \tau_{i t}^{A}+c_{2} \tau_{i t}^{B}+\varepsilon_{i t}
$$

where $\rho_{i t}$ is the A-B share premium for firm i in month $t, \tau_{i t}^{A}=\log \left(1+\right.$ turnover $\left.{ }_{i t}^{A}\right)$ and $\tau_{i t}^{B}=\log \left(1+\right.$ turnover $\left.{ }_{i t}^{B}\right)$. The estimation is based on an unbalanced panel of 75 stocks from April 1993 to December 2000. Specification I allows time effects and firm fixed effects, while Specification II allows time effects and firm random effects. The economic significance is defined as the parameter estimate multiplied by the standard deviation of the exogenous variable and then dividend by the standard deviation of the dependent variable. The specification test is the $\chi^{2}$ test proposed by Hausman (1978).

\begin{tabular}{lcccc}
\hline & & $\mathrm{C}_{1}$ & $\mathrm{C}_{2}$ & Adjusted R $^{2}$ \\
\hline I. Time effects and firm & Coeff. & 1.597 & -1.203 & 0.702 \\
effects & $\mathrm{t}-$ Stat & 16.740 & -3.400 & \\
& Economic Significance & 0.164 & -0.059 & \\
& & & & \\
II. Time effects and & Coeff. & 1.623 & -1.205 & 0.702 \\
random firm effects & t-Stat & 16.950 & -3.390 & \\
& Economic Significance & 0.166 & -0.059 & \\
& Specification Test against A: $\chi^{2}=0.00$ & Not Rejected \\
\hline
\end{tabular}




\section{Table 7. Explaining the Time Variation of $c_{0 t}$ (Monthly, February 1994-December 2000)}

This table presents estimates of the time-series regression:

$$
c_{0 t}=\vartheta_{0}+\vartheta_{1} r_{\text {China }}+\vartheta_{2} r_{\text {world }}+\vartheta_{3} i_{\text {ChinaSprd }}+\varepsilon_{t}
$$

where $c_{0 t}$ is the time-effect coefficient from the panel regression in Table 7 (specification I) of A-B share premium on A and B share turnover, $r_{\text {China }}$ is the Chinese 3-month deposit rate, $r_{\text {world }}$ is the U.S. 3-month treasury rate, and $i_{\text {Chinasprd }}$ is the spread between Chinese long-term bond and U.S. 10-year treasury bond. The t-statistics are computed using Newey-West autocorrelationconsistent standard errors with 6 lags.

\begin{tabular}{lccccc}
\hline & $\vartheta_{0}$ & $\vartheta_{1}$ & $\vartheta_{2}$ & $\vartheta_{3}$ & Adj. $\mathrm{R}^{2}$ \\
\hline Coefficient & -1.866 & -0.683 & 0.187 & 2.473 & 0.851 \\
t-Stat & -1.355 & -11.02 & 1.02 & 9.806 & \\
\hline
\end{tabular}


Table 8. Market Reactions to the Event of Opening B Shares to Domestic Investors in February 2001

This table presents a summary of market reactions to the opening of B shares to Chinese domestic investors on February 28, 2001.

A. Price reactions (2/16/2001 - 3/09/2001)

\begin{tabular}{llll}
\hline & $\mathrm{N}$ & Mean & STD \\
\hline A share price changes & 73 & $-0.5 \%$ & $22 \%$ \\
B share price changes & 73 & $63 \%$ & $7.3 \%$ \\
\hline
\end{tabular}

B. Changes in monthly turnover of B shares (6 months before and after)

\begin{tabular}{lcccc}
\hline & $\mathrm{N}$ & Mean & Median & STD \\
\hline Pre-event turnover & 73 & $12.3 \%$ & $10.5 \%$ & $7.7 \%$ \\
Post-event turnover & 73 & $44.4 \%$ & $44.7 \%$ & $15.8 \%$ \\
Ratio (Post/Pre) & 73 & 3.62 & 4.25 & 2.06 \\
\hline
\end{tabular}




\section{Table 9. Regression Results after the Opening of $B$ shares (Monthly, March 2001 - December 2001)}

This table summarizes several cross-sectional regressions for the period after the opening of Bshares. The reported coefficients are the time-series average of monthly estimates, weighted by the number of observations each month. The Fama-MacBeth t-stat is computed by the weighted average of the coefficients divided by the modified standard error as in Petersen (2005) to control for different sample sizes. Average Marginal $\mathrm{R}^{2}$ is the time-series average of marginal $\mathrm{R}^{2}$ of the monthly cross-sectional regressions. We also provide a t-test of significance of the coefficient change post liberalization.

\section{Part I: Cross-Sectional Regression of A-B Share Premium}

This part reports estimates for the following regression:

$$
\rho_{i t}=\frac{P_{i t}^{A}-P_{i t}^{B}}{P_{i t}^{B}}=c_{0 t}+c_{1 t} \tau_{i t}^{A}+c_{2 t} \tau_{i t}^{B}+c_{3 t} z_{i t}^{A}+c_{4 t} z_{i t}^{B}+\varepsilon_{i t}
$$

where $\tau_{i t}^{A}=\log \left(1+\right.$ turnover $\left.{ }_{i t}^{A}\right), \tau_{i t}^{B}=\log \left(1+\right.$ turnover $\left.{ }_{i t}^{B}\right), z_{i t}^{A}$ is the proportion of noprice-change days for the A-shares of firm $i$ in month $t$, and $z_{i t}^{B}$ is the proportion of no-pricechange days for the B-shares of firm $i$ in month $t$.

\section{A. Turnover Only}

\begin{tabular}{lcccccc}
\hline & $\mathrm{c}_{0 \mathrm{t}}$ & $\mathrm{c}_{1 \mathrm{t}}$ & $\mathrm{c}_{2 \mathrm{t}}$ & $\mathrm{C}_{3 \mathrm{t}}$ & $\mathrm{c}_{4 \mathrm{t}}$ & Average Adj.R $^{2}$ \\
\hline Average Coefficient & 1.975 & 0.406 & -0.433 & & 0.086 \\
FM t-Stat & 20.223 & 2.927 & -2.505 & & \\
Average Marginal $\mathrm{R}^{2}$ & - & 0.053 & 0.065 & & \\
t-test of Change & 9.937 & 5.951 & 1.364 & & \\
\hline
\end{tabular}

B. Turnover and No Price Change Days

\begin{tabular}{|c|c|c|c|c|c|c|}
\hline & $\mathrm{c}_{0 \mathrm{t}}$ & $\mathrm{c}_{1 \mathrm{t}}$ & $\mathrm{C}_{2 \mathrm{t}}$ & $\mathrm{C}_{3 \mathrm{t}}$ & $\mathrm{C}_{4 \mathrm{t}}$ & Average Adj.R ${ }^{2}$ \\
\hline Average Coefficient & 2.011 & 0.387 & -0.415 & -0.743 & -0.473 & 0.106 \\
\hline FM t-Stat & 20.615 & 2.749 & -2.390 & -1.880 & -0.600 & \\
\hline Average Marginal $\mathrm{R}^{2}$ & - & 0.052 & 0.062 & 0.010 & 0.014 & \\
\hline t-test of Change & 8.102 & 5.784 & 1.278 & 1.746 & 4.307 & \\
\hline \multicolumn{7}{|c|}{ C. No Price Change Days Only } \\
\hline & $\mathrm{c}_{0 \mathrm{t}}$ & $\mathrm{C}_{1 \mathrm{t}}$ & $\mathrm{C}_{2 \mathrm{t}}$ & $\mathrm{C}_{3 \mathrm{t}}$ & $\mathrm{C}_{4 \mathrm{t}}$ & Average Adj.R ${ }^{2}$ \\
\hline Average Coefficient & 1.927 & & & -0.953 & -0.805 & 0.026 \\
\hline FM t-Stat & 38.24 & & & -3.293 & -1.013 & \\
\hline Average Marginal $\mathrm{R}^{2}$ & - & & & 0.009 & 0.018 & \\
\hline t-test of Change & 13.05 & & & 1.937 & 5.505 & \\
\hline
\end{tabular}




\section{Part II. Cross-Sectional Relation between Turnover and Asset Float}

This part presents monthly cross-sectional regression of A-share turnover and B-share turnover, $\tau_{i t}^{A}=\log \left(1+\right.$ turnover $\left.{ }_{i t}^{A}\right)$ and $\tau_{i t}^{B}=\log \left(1+\right.$ turnover $\left.{ }_{i t}^{B}\right)$, on the corresponding asset float. Asset float is measured by the market valuation of all floating shares.

A. Summary of Cross-Sectional Regressions for A shares

$$
\tau_{i t}^{A}=\alpha_{0 t}+\alpha_{1 t} \log \left(\text { Float }_{i, t-1}^{A}\right)+\varepsilon_{i t}
$$

\begin{tabular}{lccc}
\hline & $\alpha_{0 \mathrm{t}}$ & $\alpha_{1 \mathrm{t}}$ & Average Adj. $\mathrm{R}^{2}$ \\
\hline Average Coefficient & 1.630 & -0.069 & 0.138 \\
FM t-Stat & 3.790 & -3.484 & \\
t-test of Change & -0.476 & 0.687 & \\
\hline
\end{tabular}

B. Summary of Cross-Sectional Regressions for B shares

$$
\tau_{i t}^{B}=\alpha_{0 t}+\alpha_{1 t} \log \left(\text { Float }_{i, t-1}^{B}\right)+\varepsilon_{i t}
$$

\begin{tabular}{lccc}
\hline & $\alpha_{0 \mathrm{t}}$ & $\alpha_{1 \mathrm{t}}$ & Average Adj. R $^{2}$ \\
\hline Average Coefficient & 0.766 & -0.021 & 0.020 \\
FM t-Stat & 5.995 & -6.478 & \\
t-test of Change & -5.912 & 6.921 & \\
\hline
\end{tabular}


Figure 1: Shanghai A and B Share Price Indices

Shanghai A (thin line) and B (thick line) share-price indices between January 1992 and January 2003.

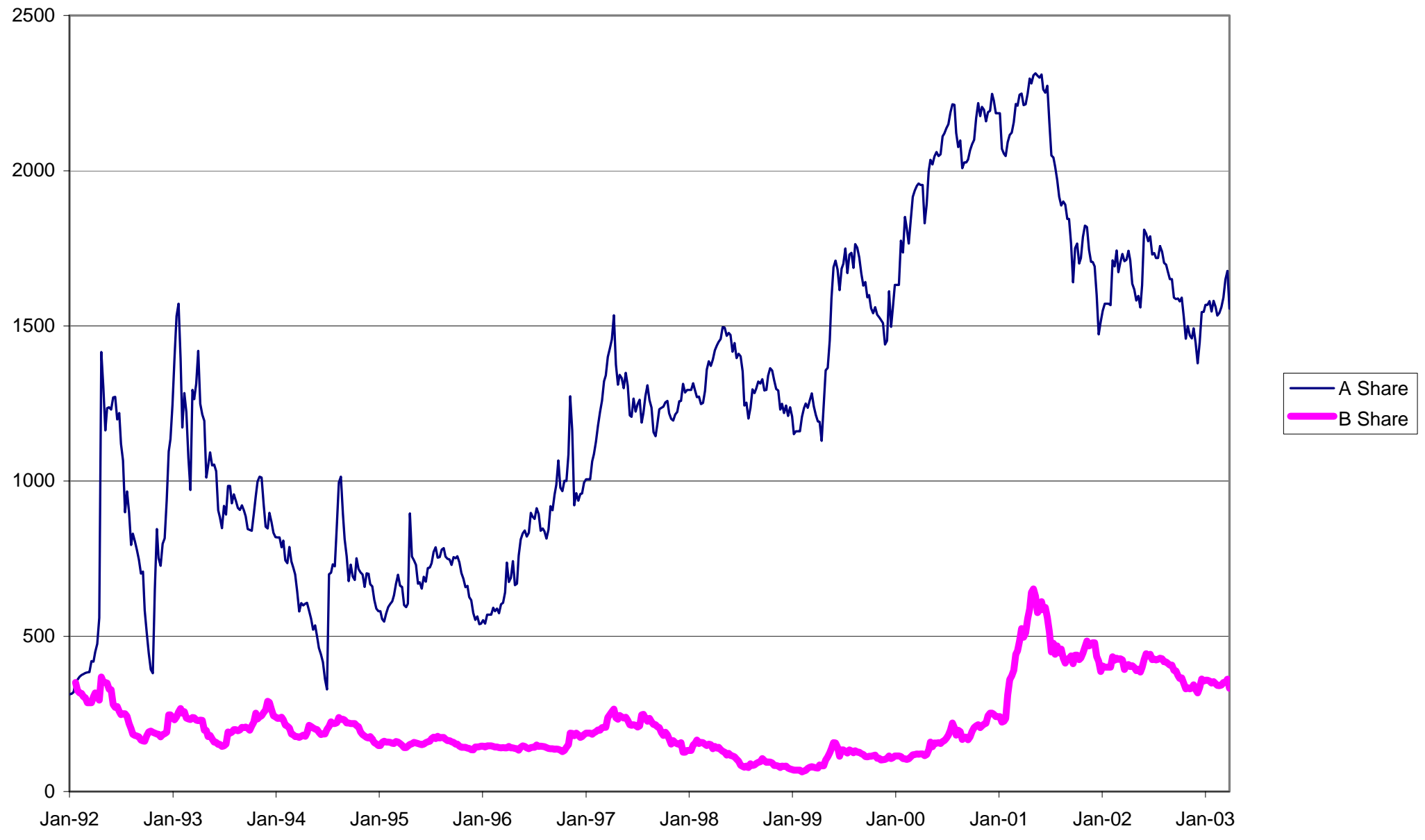


Figure 2: Average A-B Share Price Premium and Number of Firms

Average A-B share premium (thick line) and the number of firms (thin line) that had both A shares and B shares outstanding in each month for the period April 1993 - December 2001.

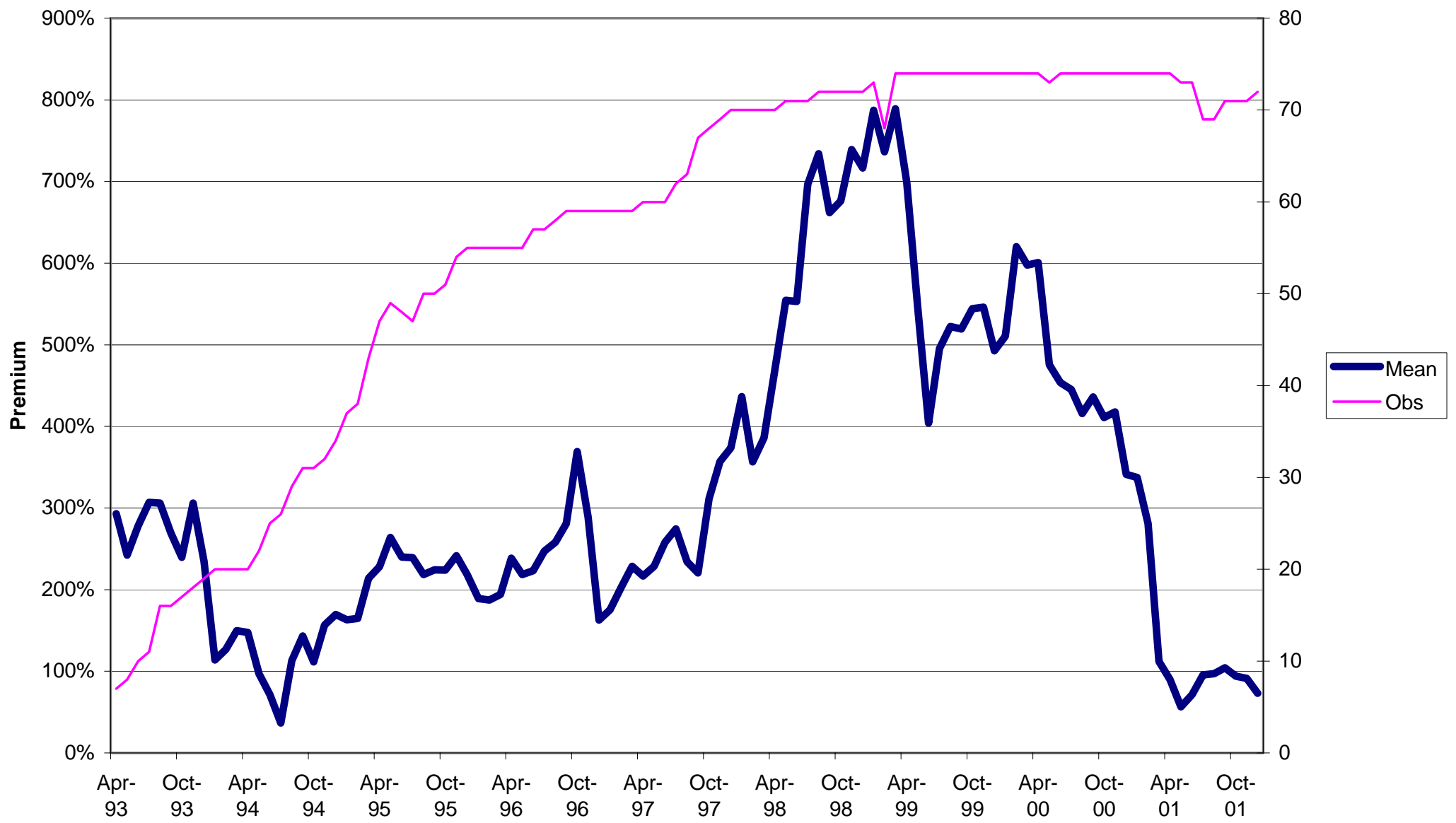


Figure 3: Cross-sectional Variation of Price Premium

The thick line is the cross-sectional standard deviation of A-B premium in sample, while the thin line is the amount of cross-sectional standard deviation explained by the regression model:

$$
\rho_{i t}=c_{0 t}+c_{1 t} \tau_{i t}^{A}+c_{2 t} \tau_{i t}^{B}+\varepsilon_{i t}
$$

where $\rho_{i t}$ is the A-B share premium for firm i in month $t, \tau_{i t}^{A}=\log \left(1+\right.$ turnover $\left.{ }_{i t}^{A}\right)$ and $\tau_{i t}^{B}=\log \left(1+\right.$ turnover $\left.{ }_{i t}^{B}\right)$.

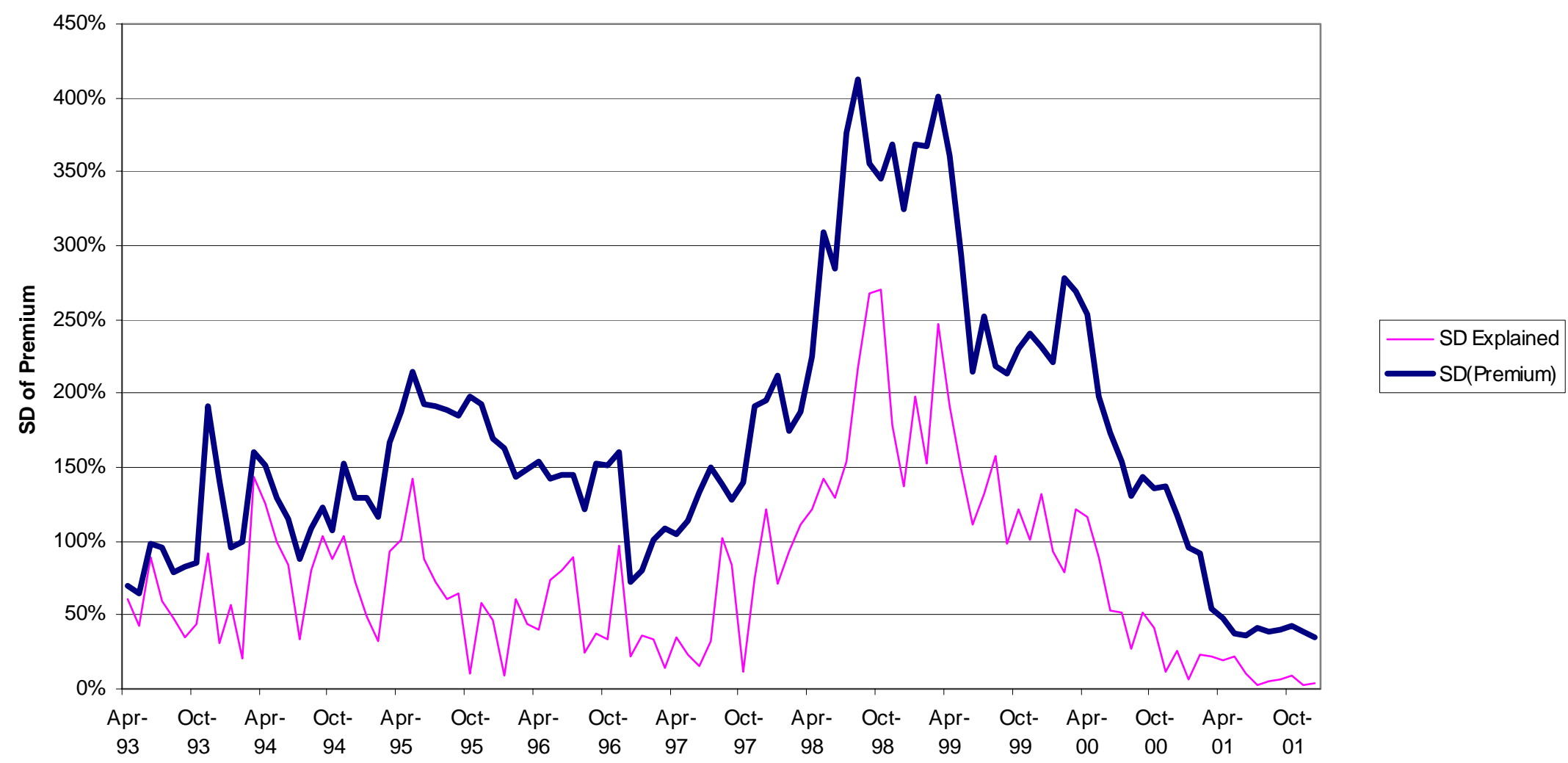

